\section{Council flat}

The EEC Council of Energy Ministers and Council of Environment Ministers both met in Luxembourg last week. Patricia Kelly and Chris Sherwell report

THE two councils held last week shared a common vein. There were no concrete decisions; and a mass of texts was referred back to national experts for further discussion. Thus it was hardly surprising that one of the most useful discussions demanded no decisions in the first place. That was the debate in the energy council on nuclear energy.

The debate had a status analogous to the open discussion at the March council on energy conservation. The Energy and Research Commissioner, Dr Guido Brunner, worried about negotiations with the US and Canada, wanted the session behind closed doors, but no one agreed. Discussion centred on Community problems relating to uranium supplies, reprocessing and waste management.

More specifically, the idea of Community responsibility for safety aspects of the fuel cycle was discussed. Unsurprisingly, some concern was expressed at the idea of handing over responsibility on a matter where political control could prove so important. The question of Community participation in the high level study set up by the recent London summit was also raised, but not pursued.

On nuclear power forecasts, Britain, together with France and Germany, found the Commission's 1985 projec. tions optimistic. Britain also criticised a suggestion, in a Community paper prepared for the meeting, for a high temperature reactor project--memories of Dragon are still fresh. There was no discussion of the vexed problem of nuclear accounting, over which a controversy, involving past uranium shipments, had blown up since the last council. The matters of nuclear costs, of public opinion and of the fast breeder could only be mentioned.

In restricted session the UK Government refused to accept what it interpreted as an enforced share-out of its North Sea ail with the rest of the Community in the event of a new world energy crisis. It was agreed that in the case of an emergency, EEC headquarters would order a $10 \%$ cut in oil consumption for two months. The Commission wanted the percentage of the cut for those countries that cannot easily find substitutes for oil to be calculated in terms of that country's oil consumption only; in countries where substitutes are more readily found, this percentage would depend on total energy consumption including oil. Italy's Carlo Donat Cattin was anxious that the Italian dependence on oil should be safeguarded in the event of a crisis. But Britain's junior minister, Dr Dickson Mabon, said that as the Community's only major energy producer, the UK was not prepared to cut its consumption more than other countries at the dictation of the Community.

It was clear that while the UK Government would be ready to help those countries most affected by an energy crisis, it could not accept a decision taken by a qualified majority vote in the council. Britain was the only country that did not want the council to depart from unanimous voting. Ministers instead agreed that if a structural problem was affecting any member state, should the Commission order a cut, the council would undertake to meet within ten days of specific proposals from the Commission.

On the matter of the minimum safeguard price for oil there was apparently little effective discussion. But the Dutch minister, Rudi Lubbers, raised the question of long-standing Dutch proposals on energy prices generally. He argued that EEC energy prices should be brought up to oil parity to encourage conservation. But Dr Mabon commented that it was too early for common pricing. The council also disagreed about Commission proposals on how to tackle overcapacity in the Community's oil refining industry. The talks foundered on the consultation system where governments would have to seek the Community's approval for new refineries to be built. On top of this, there was no discussion at the council of proposals to regulate financial support for projects exploiting alternative sources of energy.

Three coal texts were among proposals sent back for further discussion. These were the monitoring of imports from third countries, the creation of an EEC financial aid scheme to encourage the burning of coal in new power stations and a system of EEC financial support for coal stocks.

The UK Energy Secretary, Anthony Wedgwood Benn, in the chair for the last time before the new Belgian Minister for Economic Affairs, Willy Claes, takes over the council presidency, said that it had been a solid six months of work during the UK presidency. At $\mathrm{Mr}$ Benn's initiative, the council has agreed to hold a general debate at each energy council, on EEC energy and on world energy.

As for the Environment Council, this seemed doomed from the start. One observer commented that 'red mud', a by-product of the titanium dioxide industry, not only polluted the marine environment but also seemed capable of polluting the atmosphere-notably between ministers. The Italian delegation made it clear that if the council failed to agree with Commission proposals to control waste from the $\mathrm{TiO}_{2}$ and paper pulp industries-issues on which agreement has long been sought -then it would not agree to a single item on the agenda. The Italians stuck to their guns.

The Nine were split on the old question of uniform emission standards versus quality objectives as a means of control. The British argument, backed up by Ireland and Denmark, is that their industries discharge into tidal waters able to cope with large quantities of pollutants, making the Commission proposals environmentally unnecessary as well as costly to fulfil. France and Italy would like to see all Community countries impose the same controls to avoid putting industries at a competitive disadvantage. Britain maintains that what it gains on environmental cost advantages is lost on transport against more centrally placed Community countries, and was quick to point out that the dual approach to pollution control was accepted by the Nine in 1975 in a directive on the discharge of dangerous substances into the aquatic environment.

Thanks partly to the work of a working group set up during the council, some way of proceeding further may be possible, based on a distinction between reducing pollution caused by waste from an industry and reducing the quantity of the waste.

The council continued in spite of the Italian reserve. Ministers approved a decision establishing a common procedure for the exchange of information on the quality of surface fresh water in the Community. It will be formally adopted when the Italian reserve is lifted. They failed to finish discussion on EEC accession to the Helsinki Convention on protection of the Baltic. Authorisation to open negotiations is expected. Differences between the Dutch and countries through which the Rhine flows before reaching Holland meant no agreement was possible on proposals on the quality of drinking water. The proposals go back to Coreper, the committee of EEC ambassadors, for further discussion. So do proposals on toxic and dangerous waste on which the council did reach a consensus on the main aspects; a directive is expected soon. 